\title{
Solidarity across Cultures: Working Together For Democracy
}

\author{
Anwar Ibrahim \\ The leader of Malay opposition and ex Deputy of Malaysian Prime Minister
}

\begin{abstract}
At the heart of the matter in diversity, the balancing of minority interests with the majority requires ingenuous commitment from both sides as represented by their respective community leaders. Religious strife of whatever denomination or faith would seriously undermine the very foundation of constitutional democracy. There is therefore much sense in the saying that the empowerment of one cultural group at the expense of another in any society would only lead to a clash of interests. This clash if left unchecked would threaten the essential overlapping consensus, recognized as a central feature of the kind of democracy that we are talking about.
\end{abstract}

Key Words: solidarity; democracy; stability; the rule of law

\section{Introduction}

On Tuesday, early April , 2010, a people's revolt in Kyrgzstan led by the opposition saw the government of President Bakiyev crumble. The next day, about 3,000 people stormed the Parliament in Bangkok and occupied it for about two hours while thousands more occupied the capital's commercial district for a fifth day. This might or might not have led to a similar regime change but the imposition of martial law has put the matter at rest, at least for the moment. If we turn the clock back 60 years or so, we witness the Democrat Party winning an overwhelming victory in Turkey's first democratic election after decades of autocratic rule. This may be rather arbitrary but we could trace the seeds of this sea change to 1938, when the Turkish poet Nazim Hikmet was sentenced to twenty-eight years' jail after a sham trial held on a war ship. His poem, The Epic of Sheik Bedreddin, had fred an uprising in a classic case of solidarity across cultures, where Muslim, Christian, and Jewish Turks joined hands to fight oppression for the cause of freedom and democracy.

Nevertheless, there are still apologists, diehard skeptics and proponents of autocracy who say that democracy is not meant for all cultures because it is largely a Western construct and certainly not the only system for the rest of the world, let alone the best system. Asian values, for example, are said to be inherently incompatible with liberal democracy. The argument goes that the fundamental teachings of Confucius place great importance on filial piety and submission to state authority. Democracy on the other hand goes the opposite direction by putting individual liberty ahead of the betterment of society.

The Asian values mantra of societal stability and paternalism were foisted on the people to drive home the message that authoritarian systems were better suited towards achieving certain economic objectives. Western notions of human rights and freedom were a stumbling block in the eradication of poverty and the path to modernization and global competitiveness. Indeed this ideology of a strong paternalistic government being the better alternative to liberal democracy appears continues to be gaining traction among certain leaders. Yes, we cannot deny that in the context of formulating a workable development model in Asia, authoritarian regimes appear to have chalked up some advances. The positive pointers are said to be in the areas of GDP growth, raising the standard of living and greater competitiveness in an increasingly 
Konfrontasi: Jurnal Kultur, Ekonomi dan Perubahan Sosial, 6 (2) July 2019, 44-47

P-ISSN: 1410-881X (Print)

Anwar Ibrahim, Solidarity across Cultures: Working Together For Democracy

DOI: -

http://www.konfrontasi.net/index.php/konfrontasi2

globalized world, not with standing the challenges corruption, abject poverty seen in the gini coeffcient data and marginalization of groups.

\section{Thus, this begs the question: what price development?}

We cannot deny too that in Asia, hardly three decades had passed before the euphoria of independence had been replaced with autocrats and dictators. As the concept of the rule of law was turned on its head, the guns of the law were turned on the people. And as the people became more vocal in their opposition to the powers that be, newspapers were threatened with closure unless they practiced self-censored, reform movements that had mushroomed in the universities were cowed into silence, and labour unions were systematically disbanded. Leaders of opposition parties and dissidents were incarcerated under draconian laws and no effort was spared in the war against 'subversive elements' and the 'enemies' of the people.

But the people fought back. South Korea, with her Confucian ethical roots, has effectively exposed the hollowness of the Asian values mantra. The commitment to democracy and freedom did not come at the expense of economic development. Taiwan, at one time indeed one of the poster boys for the East Asian economic miracle, has paid the price of the Asian values authoritarian model. But today, it is clearly on the road to democracy. The peoples of the Philippines, Thailand and Indonesia, respectively with predominantly Christian, Buddhist, and Muslim populations, have demonstrated that culture is no barrier when it comes to freedom and democracy. What is clear is that these countries show up the 'Asian values' argument as well as the 'we-are-not-yet-ready-for-democracy' excuse as nothing more than a doctrine for the justifcation of authoritarian rule over representative and responsible government. Therefore, Asian peoples, with its diversity in culture, ethnicity and religious traditions, have shown that they too value and cherish democratic institutions and freedoms. However, it is also true that it has not been smooth sailing.

In the case of democracy and Islam, I believe the argument of incompa- tibility has lost traction, thankfully. Freedom is considered one of the higher objectives of the divine law (maqasid shariah). In fact, not just freedom, but the same crucial elements in a constitutional democracy become moral imperatives in Islam - the freedom of conscience, freedom to speak out against tyranny, sanctity of life and right to property, gender equality and a call to reform.

Indeed, if we believe that there can be a convergence of aims across cultures for the cause of freedom and democracy, we can reasonably talk of a Fourth Wave of democratization having come under way. This is democracy of a truly constitutional kind coming as a package with entrenched safeguards and power to be exercised with full accountability and transparency.

I was in Surabaya in late January when I saw the news on television about the thousands of people protesting in the streets of Jakarta against President Yudhoyono. But he did not order troops to fire water cannon on the protesters or to use tear gas to break them up because in his words, "democracy means expressing opinions, thoughts, and criticism." And he advised the people to uphold the law and obey the Constitution.

So the Fourth Wave might well find its epicenter here in Indonesia. There is press freedom and elections are conducted freely and fairly. Significant changes are seen in areas of governance where the checks and balance are getting institutionalized. The judiciary may be mired in controversy but that is not borne by the complicity of the state. Rule of law generally prevails while institutions of power remain under the watchful eye of the anti- corruption agency. It is certainly no Utopia but as a nation emerging from three decades of dictatorship, I dare say that Indonesia is by far the most exemplary of nascent liberal democracies. And it is all 
Konfrontasi: Jurnal Kultur, Ekonomi dan Perubahan Sosial, 6 (2) July 2019, 44-47

P-ISSN: 1410-881X (Print)

Anwar Ibrahim, Solidarity across Cultures: Working Together For Democracy

DOI: -

http://www.konfrontasi.net/index.php/konfrontasi2

the more remarkable considering that it is a predominantly Muslim nation in as much it completely demolishes the layers of prejudice built on the doctrine that Islam and democracy are diametrically opposed.

I would go further to say that the Indonesia phenomenon demonstrates that the when the seeds of democracy are implanted in the hearts of the people, and when the passion for freedom and democracy is ignited neither the weight of three decades of authoritarian rule nor the temptations of material wealth and economic progress can make them settle for anything less.

There are still fundamental issues to be resolved because democracy may only serve as a facade for the aggrandizement of power and wealth through the back unless and until constitutional safeguards are put in place. And this must come hand in hand with good governance, transparency and accountability.

As opposed to sham democracies or autocracies in democratic skin, real democracies can only spring forth from elections that are free, fair and transparent. There must be a "level playing feld". This means equal access to a free media, open debates and a conduct of elections that can stand up to scrutiny. Opposition parties and candidates must enjoy the freedom of speech, assembly, and movement necessary to voice their criticisms of the government openly and to bring alternative policies and candidates to the voters.

If democracy is participatory government in its fullest sense, then the existence of a vibrant opposition and civil society organizations is essential as the bulwark against the tyranny of absolute power, not be just merely tolerated but must be allowed to fourish as the people's conscience.

The rule of law and the protection of fundamental liberties are key features of a free and democratic society. To protect these basic rights, an inde- pendent judiciary is essential without which there can be no effective check and balance against the powers of the executive and the legislative branches of government. If judges are to be independent of political authority, then their positions must be protected by the constitution. Appointments to high judicial office must also be transparent and done in the most scrupulous manner. Or what can we say about judicial impartiality when decisions in constitutional cases are as a matter of fact overturned by the appellate courts so as to favour the ruling political party? Under such circumstances, can we reasonably expect judges to protect citizens against governmental arbitra- riness and political despotism?

It is therefore pertinent that we remind ourselves what this Fourth Wave of democratization must include for it to have any meaning. If we agree that a constitutional democracy must concern itself with the protection of minorities as well, government must ensure that their rights and liberties be not infringed even if it may entail the loss of popularity with the majority. Naturally this would entail making adjustments to overlapping claims to entitlement of rights or competing goals. Among the most signifcant of these competing claims is religion where history has shown that attempts by one community to impose its will on another will only lead to disharmony and eventual violence and bloodshed.

No doubt religious harmony can only be realized by making compromises from both sides. Leaders of democratic regimes must therefore not just attempt to play to the gallery or engage in grandstanding whenever the situation suits them. They must not blow hot and blow cold. They cannot on the one hand pride themselves as leading the way for cultural and ethnic harmony while on the other hand furtively stoke the fres of religious animosity through statecontrolled media and other organs of propaganda. 
Konfrontasi: Jurnal Kultur, Ekonomi dan Perubahan Sosial, 6 (2) July 2019, 44-47

P-ISSN: 1410-881X (Print)

Anwar Ibrahim, Solidarity across Cultures: Working Together For Democracy

DOI: -

http://www.konfrontasi.net/index.php/konfrontasi2

At the heart of the matter, the balancing of minority interests with the majority requires ingenuous commitment from both sides as represented by their respective community leaders. Religious strife of whatever denomi- nation or faith would seriously undermine the very foundation of consti- tutional democracy. There is therefore much sense in the saying that the empowerment of one cultural group at the expense of another in any society would only lead to a clash of interests. This clash if left unchecked would threaten the essential overlapping consensus, recognized as a central feature of the kind of democracy that we are talking about.

In the case of Asia, we can make her diversity in culture and religion a source of strength and richness, and the shared history of oppression and political enslavement, a further impetus to solidarity.

Yet there are still leaders who cling stubbornly to the belief that they need not heed the call for reform, freedom and democracy. There are still governments that are founded on the perpetuation of power not by free and fair elections but from arbitrary succession from the father to the son, or from one military clique to another, or even from one power elite to the next. And there are those who appear to have all the characteristics of a liberal democracy in so far as their domestic governance is concerned but they continue to violate human rights with impunity.

\section{Conclusion}

The rogue's gallery of such violators is staggering in sheer numbers. Indeed, to be truly meaningful, any talk of solidarity across cultures for the cause of freedom and democracy must take into account the serious human rights violations being perpetrated across the world. In this regard, where established multilateral institutions have failed in addressing these issues effectively, an alternative organization may be the answer. That would be one that is not beholden to any particular state, power or vested interest, and that is committed to take to task violators of human rights without fear or favour.

We can make diversity in culture and religion a source of strength and richness, and the shared history of oppression and political enslavement, a further impetus to solidarity. The fame that fres the passion for freedom and democracy must not be left to ficker, let alone die out. To keep it burning, we must remain resolute in our conviction to fight for freedom and democracy and defend it courage, honour and dignity.

\section{Bibliography}

Dalton, R.J., (2008). Citizenship Norms and the Expansion of Political Participation. PoliticalStudies, 56(1), pp. 76-98

EACEA (2013a). Youth Participation in Democratic Life. Final Report, EACEA 2010/03, LSE Enterprise, January 2013.

Inglehart, R. (1990). Culture shift in advanced industrial society. Princeton University Press.

International IDEA (Institute for Democracy and Electoral Assistance) (2008). Youth Voter Participation: Involving Today's Young in Tomorrow's Democracy. Stockholm: International IDEA.

Norris, P., ed., (1999). Critical Citizens: Global Support for Democratic Governance. Oxford: Oxford University Press.

Stoker, G., (2006). Explaining Political Disenchantment: Finding Pathways to Democratic Renewal. The Political Quarterly, 77(2), pp.184-194. 